\title{
Az interdiszciplináris rehabilitáció hatása spondylitis ankylopoeticában szenvedő betegekben
}

\author{
Hegedús Béla dr. ${ }^{1^{*}}$ - Varga János dr..$^{2,3^{*}}$ - Somfay Attila dr. ${ }^{3}$ \\ 'Szent Kozma és Damján Rehabilitációs Szakkórház, Visegrád \\ ${ }^{2}$ Országos Korányi TBC és Pulmonológiai Intézet, Budapest \\ ${ }^{3}$ Szegedi Tudományegyetem, Általános Orvostudományi Kar, Tüdőgyógyászati Tanszék, Deszk
}

\begin{abstract}
Bevezetés: A légzőszervi manifesztációval kapcsolatos komplex pulmonalis vizsgálat spondylitis ankylopoeticában szenvedő betegekben hozzájárulhat a megfelelő rehabilitációs program kialakításához. Célkitüzés: A légzésfunkciós, terhelés-élettani változók és a rehabilitációt követő életminőség-változás közötti kapcsolat vizsgálata. Módszer: A vizsgálatba 5 fó Seyfried II. stádiumú és 11 fó Seyfried III. stádiumú beteget vontak be, akik spinalis fizioterápiás, ultrahangos, masszázs- és parafinpakolásos kezelésben részesültek, személyenként 15 alkalommal, majd 8 héten keresztül, heti 3 alkalommal nagy intenzitású kerékpár-kondicionálás történt. A rehabilitáció előtt és után Bath Ankylosing Spondylitis Disease Activity Index és Bath Ankylosing Spondylitis Functional Index felvételére került sor. A rehabilitációt követően elvégezték a légzésfunkciós paraméterek és a terhelés-élettani változók vizsgálatát. Eredmények: Mindkét index jelentős, kezelés utáni változást mutatott az eredeti eredményekhez képest $(\mathrm{p}<0,05)$. Ezek a funkcionális mutatók összefüggést mutattak a nyugalmi légzésfunkciós és a terhelés-élettani változókkal $(\mathrm{p}<0,05)$. Következtetések: A vizsgálat alapján lehetséges, hogy az előzetes pulmonalis felmérés a spondylitis ankylopoetica kezelésére irányuló hatékonyabb program kidolgozásának alapjául szolgálhat. Orv. Hetil., 2016, 157(28), 1126-1132.
\end{abstract}

Kulcsszavak: spondylitis ankylopoetica, életminőség, rehabilitáció

\section{Interdisciplinary rehabilitation in patients with ankylosing spondylitis}

Introduction: Complex pulmonary assessment related to respiratory manifestation in patients with ankylosing spondylitis may contribute to adaptation of an appropriate rehabilitation program. Aim: To examine the relationship between lung function, exercise physiological variables and change in quality of life after rehabilitation in patients with ankylosing spondylitis. Method: 5 patients in Seyfried's Stage 2 and 11 patients in Stage 3 underwent spinal physiotherapy, ultrasound, massage and paraffin Pack, 15 times each, followed by a high-intensity cycling 3 times a week for 8 weeks. The Bath Ankylosing Spondylitis Disease Activity and Bath Ankylosing Spondylitis Functional Indexes were recorded before and after rehabilitation. Lung function with exercise physiological variables were examined after rehabilitation. Results: Both indexes showed a post-treatment significant improvement compared to the initial scores $(\mathrm{p}<0.05)$. These functional indices correlated with lung function at rest and physiological variables during exercise $(\mathrm{p}<0.05)$. Conclusions: Based on this study, it is possible that an initial pulmonary assessment may serve to develop a more effective program for ankylosing spondylitis.

Keywords: ankylosing spondylitis, quality of life, rehabilitation

Hegedüs, B., Varga, J., Somfay, A. [Interdisciplinary rehabilitation in patients with ankylosing spondylitis]. Orv. Hetil., 2016, 157(28), 1126-1132.

(Beérkezett: 2016. március 1.; elfogadva: 2016. április 24.)

\section{Rövidítések}

BASDAI = (Bath Ankylosing Spondylitis Disease Activity Index) Bath Spondylitis Ankylopoetica Betegség Aktivitási Index; BASFI $=($ Bath Ankylosing Spondylitis Functional Index $)$ Bath
Spondylitis Ankylopoetica Funkciós Index; $\mathrm{FEV}_{1}=$ eróltetett kilégzési másodperctérfogat; FVC = erőltetett vitálkapacitás; GPR = teljes testtartás újratanulása; HRCT = nagy felbontású számítógépes tomográfia; LAT = laktátacidózis-küszöb;

*A két szerző egyenlő arányban vett részt a közlemény elkészítésében. 
NHANES = az Amerikai Egyesült Államok országos egészségés táplálkozáskutatási vizsgálata; PFT = légzésfunkciós vizsgálat; $\mathrm{RA}=$ rheumatoid arthritis; $\mathrm{RPE}=\mathrm{az}$ érzékelt erőfeszítés mértéke; SPA = spondylitis ankylopoetica; TLC = teljes tüdőkapacitás; $\mathrm{V}_{\mathrm{E}}=$ légzési perctérfogat; $\mathrm{V}_{\max }=$ tömegáramlás-érzékelő és terhelési metabolikus mérési rendszer; $\mathrm{VCO}_{2}=$ széndioxid-leadás; $\mathrm{VO}_{2}=$ oxigénfelvétel; $\mathrm{WR}_{\max }=$ maximális terhelési kapacitás

A spondylitis ankylopoetica (SPA) krónikus, szisztémás, reumás betegség a szeronegatív spondarthritisek csoportjából, amelyet különösen a gerinc intervertebralis és costovertebralis ízületeinek és a sacroiliacalis ízületeknek a gyulladása jellemez. A betegség hat a perifériás ízületekre is, például a vállra, a csípőre és a térdre $[1,2]$. A megbetegedés során a gerinc és a mellkas jellegzetes deformitásai alakulnak ki, ami a légzési kitérés csökkenéséhez, a légzésfunkciós kapacitás beszúküuléséhez vezet. A légzésfunkciós károsodás a betegség gyakori velejárója és alapvetốn meghatározza a beteg állapotát és prognózisát $[3,4]$. A korlátozott mellkaskitérés, a beszúkuült gerincmobilitás és a fájdalom hypoventilatiót eredményez [5]. A hypoventilatio részben a csökkent légzési volumenhez és az alveolaris ventilatio, perfúzió közötti diszkrepanciához kapcsolódik. A pulmonalis manifesztáció mérsékelt alveolaris hypoxiát és a fiziológiás holttér növekedését okozhatja. A korlátozott mellkasi kitérés és relaxáció, a hypoventilatio a vitálkapacitás csökkenéséhez vezet. A hypoventilatio fertőzésre és pulmonalis fibrosis kialakulására hajlamosít $[6,7]$.

A mellkasi nagy felbontású számítógépes tomográfia (HRCT) további információkkal szolgál a mellkasröntgenhez képest. A tüdőfibrosis fő́leg a csúcsi részekre lokalizálódik. Kezdetben a pleura elvékonyodása és interstitialis infiltráció alakul ki. A hilus felső része elvékonyodik, tömör fibroticus területek alakulnak ki, és a tüdőszövet destrukciója is bekövetkezik, amelyhez emphysema és bullaképződés is társul [8].

A fibrosissal és bullaképződéssel járó esetek csaknem egyharmadában visszatérô gombás és bakteriális fertőzések alakulhatnak ki [8]. A légzésfunkciós paraméterek és az életminőség, funkcionalitás, betegségaktivitás között szignifikáns összefüggés igazolható [9].

Az SPA súlyosabb szakaszaiban a mellkas falának deformitása miatti restriktív légzészavar és a tüdőszövet fibrosisa alakul ki, valamint a pleura megvastagodása fordul elő.

Ellenőrzött légzési technikákkal és spinális fizioterápiával, kerékpár-kondicionálással javítható a gerinc mozgékonysága, a mellkas kitérése, valamint a terhelés-élettani változók [10], valószínúleg befolyásolva az olyan funkcionális eredményeket, mint a Bath Ankylosing Spondylitis Functional Index (BASFI) és a Bath Ankylosing Spondylitis Disease Activity Index (BASDAI) [11].

A rehabilitációnak az életminőségre és a légzésfunkciós változókra való hatását spondylitis ankylopoeticától szenvedő betegeknél vizsgáltuk egy 8 hetes interdiszcip- lináris rehabilitációs programban. Célunk az volt, hogy értékeljük a kompozit edzési modalitásnak az SPA-tól szenvedő betegek funkcionális és életminőségi változóira gyakorolt hatását.

\section{Módszer}

\section{Résztvevők}

A vizsgálatba 16 beteget vontunk be, akiknél korábban a New York-i kritériumok alapján diagnosztizálták a spondylitis ankylopoeticát [12]. 5 beteg Seyfried II. stádiumú, 11 beteg pedig Seyfried III. stádiumú volt [13]. A résztvevók közül 13 férfi, 3 pedig nő volt. Átlagéletkoruk 52 év volt. A gyulladásos aktivitás (gyorsult vörösvértest-süllyedés és magas $\mathrm{CRP}$ ) jelenléte kizáró ok volt a vizsgálatból (1. táblázat).

\section{Tüdöfunkció és cardiopulmonalis terheléses vizsgálat}

A betegekkel légzésfunkciós vizsgálatokat (PFT) végeztünk $\left(\mathrm{V}_{\max }\right)$ Autobox 6200 (Sensor Medics, Yorba Linda, California) eszközökkel, így például spirometriás, testpletizmográfiás és diffúzióskapacitás-méréseket [14, 15]. Normálértéknek a NHANES III. szerinti standardokat vettük [14].

Közvetlenül a PFT után inkrementális terheléses vizsgálatra került sor egy elektronikusan fékezett kerékpáros ergométerrel (Ergoline-900, Marquette). 3 perces pihenőt, majd 3 percig tartó, 20 wattos folyamatos pedálozást követốen a terhelést - fokozatosan - $10 \mathrm{~W} /$ perccel növeltük. A pedálfrekvenciát a betegek folyamatosan körülbelül $60 /$ perc értéken tartották. A légzési térfogatot $\left({ }^{\circ} \mathrm{V}_{\mathrm{E}}\right)$, a gázcserét (oxigénfelvétel [' $\left.\mathrm{VO}_{2}\right]$ ) és szén-dioxid-leadást $\left({ }^{\circ} \mathrm{VCO}_{2}\right)$ légzésről légzésre tömegáramlásmérővel terhelési metabolikus rendszerrel határoztuk meg $\left(\mathrm{V}_{\max }\right)$ (SensorMedics). Minden teszt elött bekalibráltuk a rendszert. A laktátküszöböt (LAT) a módosított „V-slope” módszerrel azonosítottuk [16]. A szívfrekvenciát 12 elvezetéses EKG-val (Cardiosoft, SensorMedics), az oxigénszaturációt pedig pulzoximéterrel (SatTrak, SensorMedics) monitoroztuk. A maximális akaratlagos ventilációt a $40 \times \mathrm{FEV}_{1}$ képlettel becsültük meg [17]. A nehézlégzés és a lábfáradás okát a csúcsteljesítménynél, módosított Borg-skálával határoztuk meg [18]. A fiziológiai adaptáció mértékének megítélésére a tréning előtt és után végzett növekvő intenzitású terhelés identikus teljesítményéhez tartozó (isotime) értékeket hasonlítottuk össze.

\section{Agerinc és a mellkasfal károsodásának mérése és a betegségaktivitás}

Az ízületi funkció mérésére a légzési kitérést, a lumbalis Schober-értéket, a lumbalis gerinc lateralis elhajlásának 
1. táblázat | Betegkarakterisztika

\begin{tabular}{|c|c|c|}
\hline \multicolumn{3}{|c|}{ Vizsgált paraméterek } \\
\hline \multicolumn{2}{|l|}{ Kor (év) } & $52,38 \pm 23,1$ \\
\hline \multirow{2}{*}{$\begin{array}{l}\text { Mellkasröntgen } \\
\text { Mellkasi HRCT }\end{array}$} & Bronchiectasia & 5 \\
\hline & Pleura megvastagodása & 3 \\
\hline \multicolumn{2}{|c|}{ Lumbalis Schober $(\mathrm{cm})$} & $1,96 \pm 1,11$ \\
\hline \multicolumn{2}{|c|}{ Ujj-padló távolság (cm) } & $29,20 \pm 13,44$ \\
\hline \multicolumn{2}{|c|}{ Légzési kitérés (cm) } & $1,65 \pm 1,05$ \\
\hline \multicolumn{2}{|c|}{$\begin{array}{l}\text { Vörösvértest-süllyedés }(\mathrm{mm} / \mathrm{h}) \text {; } \\
\text { normális: } 15\end{array}$} & $13 \pm 9$ \\
\hline \multicolumn{2}{|c|}{ CRP (mg/l); normális: 5} & $4,9 \pm 3,1$ \\
\hline
\end{tabular}

$\mathrm{CRP}$ = C-reaktív protein; HRCT = nagy felbontású számítógépes tomográfia

2. táblázat A rehabilitáció hatása a funkcionális indexekre, légzésfunkciós paraméterekre és terhelés-élettani változókra spondylitis ankylopoeticában

\begin{tabular}{|c|c|c|c|}
\hline Vizsgált paraméterek & $\begin{array}{l}\text { Kezelés } \\
\text { előtt }\end{array}$ & $\begin{array}{l}\text { Kezelés } \\
\text { után }\end{array}$ & $\begin{array}{l}\text { Statisztikai } \\
\text { szignifikancia (p) }\end{array}$ \\
\hline BASFI (átlag) & $7,9 \pm 5,4$ & $5,1 \pm 3,5$ & n. sz. \\
\hline BASDAI (átlag) & $8,0 \pm 3,5$ & $6,1 \pm 2,1$ & n. sz. \\
\hline BASFI I. & $7,8 \pm 2,4$ & $4,5 \pm 2,2$ & $\mathrm{p}<0,05$ \\
\hline BASFI II. & $7,9 \pm 2,4$ & $4,1 \pm 1,6$ & $\mathrm{p}<0,05$ \\
\hline BASFI III. & $7,2 \pm 2,2$ & $6,3 \pm 1,8$ & $\mathrm{p}<0,05$ \\
\hline BASFI IV. & $6,7 \pm 2,8$ & $6,6 \pm 2,0$ & n. sz. \\
\hline BASFI V. & $8,2 \pm 2,4$ & $4,2 \pm 1,6$ & $\mathrm{p}<0,05$ \\
\hline BASDAI I. & $7,7 \pm 2,0$ & $4,9 \pm 1,3$ & $\mathrm{p}<0,05$ \\
\hline BASDAI II. & $7,9 \pm 2,3$ & $4,8 \pm 1,8$ & $\mathrm{p}<0,05$ \\
\hline $\mathrm{FEV}_{1}($ ref. \%) & $75 \pm 18$ & $77 \pm 17$ & n. sz. \\
\hline FVC (ref. \%) & $80 \pm 16$ & $86 \pm 19$ & n. sz. \\
\hline $\mathrm{FEV}_{1} / \mathrm{FVC}(\%)$ & $67 \pm 8$ & $68 \pm 6$ & n. sz. \\
\hline TLC (ref. \%) & $91 \pm 11$ & $84 \pm 22$ & n. sz. \\
\hline DLCO (ref. \%) & $68 \pm 23$ & $77 \pm 27$ & n. sz. \\
\hline $\mathrm{WR}_{\max }$ & $79 \pm 23$ & $90 \pm 22$ & $\mathrm{p}<0,05$ \\
\hline $\mathrm{VO}_{2} / \mathrm{kg}($ ref. $\%)$ & $72 \pm 15$ & $73 \pm 15$ & n. sz. \\
\hline LAT $\left(\mathrm{VO}_{2 \max }\right.$, pred. $\left.\%\right)$ & $53 \pm 13$ & $55 \pm 12$ & n. sz. \\
\hline Borg (nehézlégzés) & $7 \pm 2$ & $7 \pm 2$ & n. sz. \\
\hline Borg (lábfáradás) & $9 \pm 1$ & $8 \pm 2$ & n. sz. \\
\hline
\end{tabular}

Az adatokat átlag \pm SD-ként számoltuk.

BASDAI = Bath Ankylosing Spondylitis Disease Activity Index; BASFI = Bath Ankylosing Spondylitis Functional Index; DLCO = szén-monoxid-diffúziós kapacitás; $\mathrm{FEV}_{1}=$ eróltetett kilégzési másodperctérfogat; FVC = erőltetett vitálkapacitás; LAT = laktátküszöb; TLC = teljes tüdőkapacitás; $\mathrm{VO}_{2}=$ aerob kapacitás.

mértékét és az ujj-padló távolságot használtuk. A következő laboratóriumi vizsgálatok jelezték a betegség aktivitását: süllyedés, CRP, Hgb, hematokrit, fehérvérsejt és immunoglobulinok. A gerinc érintettségét kétirányú röntgennel, a tüdő érintettségét pedig mellkasröntgennel és mellkas-HRCT-vel határoztuk meg (1. táblázat).

\section{Rehabilitációs program}

A betegeket egy komplex rehabilitációs program részeként spinalis fizioterápiával [19], paravertebralis ultrahanggal, masszázzsal és parafinpakolással kezeltük [19], minden betegnél 15 alkalommal. Nagy intenzitású kerékpár-kondicionálás (hasonló a COPD-től szenvedő betegekéhez, a maximális terhelési kapacitás 80\%-a) [20] és ellenőrzött légzéstechnikák [21] alkalmazására szintén sor került 8 héten keresztül, heti 3 alkalommal, alkalmanként 30 percig.

\section{Az életminöség mérése}

A rehabilitáció előtt és után BASFI [22] és BASDAI [23] funkcionális indexek felvételére került sor. A rehabilitáció hatásának meghatározásához megvizsgáltuk a funkcionális indexek (BASFI és BASDAI) változását, valamint az e funkcionális indexeknek a légzésfunkciós paraméterekkel és a terheléses fiziológiai változókkal való korrelációját.

\section{Statisztikai elemzés}

A pre- és posztrehabilitációs csoportokat a Student-féle $t$-próbával vetettük össze, a folyamatos és kategorikus változókat pedig $\chi^{2}$-próbával. A p $<0,05$ értéket tartottuk szignifikánsnak. A középérték körüli eloszlást átlag \pm SDként számoltuk, azon értékek kivételével, ahol a \pm SE-t használtuk. A normáleloszlást Kolmogorov-Szmirnovteszttel vizsgáltuk, szignifikanciaként a p<0,05 értéket fogadtuk el. Felmértük az értékminőség és a légzésfunkciós paraméterek közötti korrelációt. A korreláció határozottabb volt, ha az (r) korrelációs együttható a $-1,0$ értékhez közelített, $\mathrm{p}<0,05$ szignifikanciával $[24,25]$.

A betegek beleegyező nyilatkozatot adtak a vizsgálathoz, az intézmény kutatási etikai bizottsága pedig engedélyt adott a vizsgálat elvégzésére.

\section{Eredmények}

A betegek demográfiai adatait az 1. táblázat tartalmazza. A laboratóriumi vizsgálatok szerint a betegség nem mutatott gyulladásos aktivitást. A 16 beteg közül 5-nél fordult elő bronchiectasia, 3-nál pedig a pleura megvastagodása (1. táblázat). A tüdőfunkció enyhe restrikciót, obstruktív légúti betegséget és csökkent diffúziókapacitást mutatott (2. táblázat). A terhelési kapacitás $\left(\mathrm{WR}_{\max }\right)$ és az aerob kapacitás $\left(\mathrm{VO}_{2} / \mathrm{kg}\right)$ jelentős mértékben csökkent volt a rehabilitáció előtt (2. táblázat). A Borgskála a tünetek nagyobb értékét mutatta (nehézlégzés, lábfáradás) rehabilitáció előtt (2. táblázat).

A rehabilitáció hatásaként a maximális terhelési kapacitás jelentősen javult $\left(\mathrm{WR}_{\max }: 79 \pm 23 \mathrm{~W}\right.$ és $90 \pm 22 \mathrm{~W}$; $\mathrm{p}<0,05)$ (2. táblázat). A terheléses fiziológiai változók és a Borg-skála csupán enyhe javuló tendenciát mutatott rehabilitáció után (2. táblázat). 




1. ábra

\begin{tabular}{|l} 
A BASFI változása a rehabilitáció eredményeként \\
I. Felvenni valamit a földről. \\
II. Leemelni valamit a polcról. \\
III. Szokásos munkahelyi tevékenység. \\
IV. Fotelból felkelés esetében elért változás. \\
V. A kezeléssel a „Hátranézni megfordulás nélkül” esetében \\
elért változás. \\
*Szignifikanciaszint (p<0,05) \\
(a: kezelés előtt, b: kezelés után)
\end{tabular}

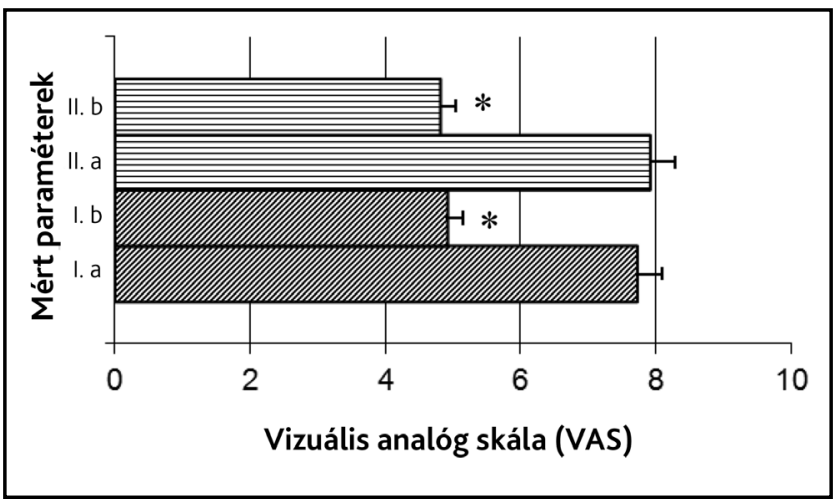

2. ábra

A BASDAI változása a rehabilitáció eredményeként
I. Erôs nyomásérzékenység bárhol.
II. Zavaró reggeli gerincmerevség.
*Szignifikanciaszint $(\mathrm{p}<0,05)$
(a: kezelés előtt, b: kezelés után)

3. táblázat |A pulmonalis funkcióindexek és az életminőség korrelációja

\begin{tabular}{lcc}
\hline Vizsgált paraméterek & Korreláció (R) & Szignifikanciaszint \\
\hline BASFI III. - TLC (ref. \%) & $-0,86$ & 0,014 \\
BASFI IV. - TLC (ref. \%) & $-0,94$ & 0,002 \\
BASDAI I. - TLC (ref. \%) & $-0,83$ & 0,020 \\
BASDAI II. - TLC (ref. \%) & $-0,78$ & 0,040 \\
BASDAI I. - WR & $-0,51$ & 0,042 \\
BASFI IV. - LAT & $-0,51$ & 0,045 \\
VO $_{2 \max }$, pred. \%) & & \\
\hline
\end{tabular}

BASDAI = Bath Ankylosing Spondylitis Disease Activity Index; BASFI = Bath Ankylosing Spondylitis Functional Index; LAT = laktátküszöb; TLC $=$ teljes tüdőkapacitás
Ami a funkcionális indexeket illeti, a BASFI a következő eredmények tekintetében mutatott szignifikáns javulást (a: kezelés előtt, b: kezelés után):

- felvenni valamit a földről;

- leemelni valamit a polcról;

- szokásos munkahelyi tevékenység végzése;

- hátranézni megfordulás nélkül (2. táblázat, 1. ábra).

A BASDAI szerint a rehabilitáció szignifikáns javulást hozott a következő pontoknál (a: kezelés előtt, b: kezelés után):

- erős nyomásérzékenység bárhol;

- zavaró reggeli gerincmerevség (2. táblázat, 2. ábra).

A rehabilitációt követóen a légzésfunkciós paraméterek, a terhelés-élettani változók, a BASFI és a BASDAI közötti összefüggések vizsgálata céljából Pearson-korrelációanalízist végeztünk. A TLC (ref. \%) a következő funkcionális indexekkel mutatott korrelációt: BASFI III., BASFI IV., BASDAI I. és BASDAI II. (3. táblázat). A terheléses fiziológiai változók a következő paraméterekkel mutattak korrelációt: BASDAI I. - $\mathrm{WR}_{\max }$ és BASFI IV. - LAT (3. táblázat). Viszonylag gyenge korreláció mutatkozott az életminőség-paraméterekkel a $\mathrm{WR}_{\max }$ és a LAT $\left(\mathrm{VO}_{2 \max }\right.$, pred. \%) vonatkozásában (3. táblázat).

Az interdiszciplináris rehabilitációs program a BASFI és a BASDAI szerint mérve jobb életminőséget eredményezett a mindennapos tevékenységek tekintetében. A BASDAI-skála kevésbé szenzitív a rehabilitációra; csak a nyomásérzékenységgel és a reggeli merevséggel kapcsolatos változások voltak szignifikánsak. A rehabilitáció eredményeként javult a maximális terhelési kapacitás.

\section{Megbeszélés}

Az SPA esetében mellkasi merevség alakul ki: a hátcsigolya, valamint a costovertebralis, a costotransversalis, a sternoclavicularis és a manubriosternalis ízületek merevsége. A mellkas merevségét a progresszív kyphosis okozta deformitás súlyosbítja [21]. A tüdő involválódása az SPA ritka és késői manifesztációja. Apicalis fibrosis jellemezheti. A légzési térfogat általában megfelelő, a rekeszizom intenzívebb részvétele a légzésben pedig némileg kompenzálja a mellkasfali merevséget [26]. Az SPA-ban a légzésfunkció jellemző abnormalitásai megegyeznek a tipikus restriktív légzési elégtelenségekével; a légzésfunkciós vizsgálatok restriktív változásokat igazoltak, csökkent FVC- és $\mathrm{FEV}_{1}$-értékkel, de normális $\mathrm{FEV}_{\mathrm{l}} /$ FVC értékkel [27].

A TLC (ref. \%) mint a restrikció mértéke korrelál a napi tevékenységekkel. Ez a paraméter a restrikció fokát mutatva jól korrelált a betegség manifesztációjával [28]. A vizsgált esetekben nem volt kifejezett a betegség pulmonalis manifesztációja, a TLC-érték nem volt szignifikánsan alacsonyabb a referenciaértékeknél.

A légzési kitérés limitációja és a vitálkapacitás restrikciója közötti kapcsolatot Feltelius és mtsai mutatták meg [29]. A légzési kitérés és a módosított Schober alacso- 
nyabb lehet az SPA-ban szenvedők azon csoportjánál, ahol a tüdőfunkció károsodásának restriktív típusa van jelen.

A rheumatoid arthritis (RA) és az osteoarthritis esetében a terheléssel szembeni kisebb tolerancia figyelhető meg a kontrollcsoporthoz képest, különösen az RA-ban szenvedők csoportjánál [29, 30]. Vizsgálatunk során azonban úgy találtuk, hogy a terheléses vizsgálatnál az SPA-betegek csoportját jobban befolyásolta a fizikai terhelés, a betegek pedig nagyobb mértékü légzőszervi tünetekről, például nehézlégzésről számoltak be. Az érzékelt erőfeszítés mértékének (RPE) nagyobb értéke volt megfigyelhető a légzésfunkciók nagyobb igénybevétele miatt. Carter és mtsai ugyanakkor nagyobb mértékü lábfáradást és hasonló mértékü nehézlégzést észleltek az SPA-betegeknél, mint a kontrollcsoportnál [31]. A terheléssel szembeni intolerancia az erőnlét romlása miatti periferiális izomfunkció romlásával lehet kapcsolatos. Az RPE különbsége annak tulajdonítható, hogy az SPA-betegek csoportjában korlátozott a mellkasfal mozgása. A maximális aerob kapacitás nem mutatott korrelációt a légzési kitéréssel, a vitálkapacitással azonban igen [31]. A mellkasfali restrikciótól szenvedő SPA-betegeknél csökkent terheléses teljesítményt találtak [32]. A VO ${ }_{2 \max }$ megfigyelt csökkenéséért az erőnlét romlása és a cardiovascularis funkcióknak a légzési funkciók romlásához mért romlása tehető felelőssé [32]. Eredményeink arra utalnak, hogy noha a légzési kitérés enyhe korlátozása a légzési tartalék csökkenését eredményezheti, nem volt jelentős tényező a terheléssel szembeni tolerancia meghatározásakor.

Mau és mtsai 32 SPA-beteget vizsgáltak meg (náluk a beteg állapot átlagosan 18 éve állt fenn), és azt állapították meg, 78\%-uknál jó vagy kielégítő volt a funkcionális kapacitás, ami összességében jó funkcionális prognózist jelez [33]. Egy hosszú távú, a funkcionális kapacitás fokozatos elvesztésével kapcsolatos morbiditási vizsgálatban Ringsdal és Helin úgy találta, hogy a betegek $85 \%$-a még több mint 20 éves beteg állapot után is munkaképes maradt [34]. Saját vizsgálatunkban nem találtunk korrelációt a beteg állapot fennállásának időtartama és a tüdőfunkció vagy a terheléssel szembeni tolerancia között. Mivel az alacsonyabb BASFI-értékek jobb funkcionális képességeket mutattak, az eredmények azzal magyarázhatók, hogy az SPA-betegek adott csoportjánál a betegség hosszú időtartamához megfelelő fizikai tevékenységi szint párosult. A terhelést egyre szélesebb körben ajánlják, mint a helyes testtartás megőrzésének, a gerinc rugalmassága javításának és a hátfájás csökkentésének eszközét [34]. Azok a vizsgálati alanyok, akik mérsékelt napi testgyakorlást végeztek, a referenciaértékeikhez közeli maximális aerob kapacitást tudtak elérni, a korlátozott légzési kitérés ellenére. Nagyobb hangsúlyt kell fektetni az SPA-betegeknek szóló tanácsadásra, és arra való ösztönzésükre, hogy terheljék rendszeresebben magukat és sportoljanak [35].
A pleuropulmonalis érintettség előfordulása az SPAban a beszámolók szerint 0 és 30\% között változik [3638]. A pulmonalis érintettség a betegség ritka és kései extraskeletalis manifesztációja. Az SPA leggyakrabban rögzített és jól ismert patológiája az apicalis fibrosis. $\mathrm{E}$ betegeknél bronchiolitis obliterans, tracheobronchomegalia, gombafertőzés kialakulása, cor pulmonale, pleuralis folyadékgyülem és pneumothorax előfordulásáról szintén beszámoltak [16, 21]. A legnagyobb sorozatról Rosenow és mtsai számoltak be [38]. A Mayo Klinika 2080 SPA-betegénél a csúcsi részek fibrosisát állapították meg a leggyakrabban, 1,2\%-os előfordulással [38]. A patológiás állapot a felső tüdőcsúcsok lassú előhaladású fibrosisa, amely átlagosan két évtizeddel az SPA kialakulása után jelenik meg [38]. Rendszerint kétoldali és lineáris vagy foltos opacitásként látható a mellkasi röntgenfelvételeken. A fibrosis végül cisztássá alakul. Ezekben az üregekben aspergillosis alakulhat ki [38].

A rendszeres tréning fó célja a gerinc és a perifériás ízületek mobilitásának megőrzése és javítása, a törzs, a láb, a hát és a has izmainak erősítése, valamint a funkciós kapacitás és az életminőség javítása [39-41]. A források számos tréningprotokollról beszámolnak az SPA vonatkozásában [42-44], ám nehéz összevetni e protokollok hatásait. Fernandez-de-Las-Penas és mtsai [44] két különböző testgyakorlási módszert hasonlítottak össze, és az eredmények azt mutatták, hogy a teljes testtartás újratanulásának (global posture reeducation - GPR) módszerével kezelt betegeknél nagyobb javulást sikerült elérni a funkcionalitás és a mobilitás eredményeiben, mint a hagyományos tréninggel kezelt betegeknél [44]. Ugyanakkor Fernández-de-Las-Peñas és mtsai nem értékelték a tréning tüdókapacitásra gyakorolt hatásait [44]. Ezért célunk volt az is, hogy megvizsgáljuk a GPR-módszernek az SPA-betegek pulmonalis funkcióira és terheléses fiziológiai változóira gyakorolt lehetséges hatásait. Vizsgálatunk során nagy intenzitású kerékpár-kondicionálást alkalmaztunk (a COPD-hez hasonlóan).

Vizsgálatunknak korlátai vannak. A II. és III. stádiumú betegeknél nincs súlyos mellkasfali restrikció vagy tüdőfibrosis. A súlyosabb esetekben a tüdő érintettsége elméletben nagyobb. Ilyen esetekben a hatás nagyobb lehet az interdiszciplináris rehabilitáció során.

\section{Következtetések}

Véleményünk szerint célszerű az SPA-s betegeknél a rehabilitációt megelőzően állapotfelmérést végezni, és ennek alapján összeállítani az interdiszciplináris rehabilitációs programot a kísérleti vizsgálatban. Az interdiszciplináris rehabilitációs program a BASFI és a BASDAI szerint mérve jobb életminőséget eredményezett a mindennapos tevékenységek vonatkozásában. A rehabilitáció eredményeként javult a maximális terhelési kapacitás, a légzési változók azonban nem módosultak jelentős mértékben. 
Anyagi támogatás: A közlemény megírása anyagi támogatásban nem részesült.

Szerzôi munkamegosztás: H. B., V. J.: A klinikai vizsgálatok elvégzése, adatgyújtés, a klinikai megállapítások értelmezése, statisztikai elemzés, a kézirat egy részének megírása. S. A.: A projekt megvalósítása, a klinikai megállapítások értelmezése, a kézirat egyik részének megírása, a kézirat felügyelete.

Érdekeltség: A szerzőknek nincsenek érdekeltségeik.

\section{Irodalom}

[1] Braun, J., van der Heijde, V. D.: Imaging and scoring in ankylosing spondylitis. Best Pract. Res. Clin. Rheumatol., 2002, 16(4), 573-604.

[2] Dougados, M., Dijkmans, B., Khan, M., et al.: Conventional treatments for ankylosing spondylitis. Ann. Rheum. Dis., 2002, 61(Suppl. 3), iii40-iii50.

[3] Fisher, L. R., Cawley, M. I., Holgate, S. T.: Relation between chest expansion, pulmonary function and exercise tolerance in patients with ankylosing spondylitis. Ann. Rheum. Dis., 1990, 49(11), 921-925.

[4] Feltelius, N., Hedenström, H., Hillerdal, G., et al.: Pulmonary involvement in ankylosing spondylitis. Ann. Rheum. Dis., 1986, 45(9), 736-740.

[5] Elliott, C. G., Hill, T. R., Adams, T. E., et al.: Exercise performance of subjects with ankylosing spondylitis and limited chest expansion. Bull. Eur. Physiopathol. Respir., 1985, 21(4), 363368.

[6] Seçkin, U., Bölükbasi, N., Gürsel, G., et al.: Relationship between pulmonary function and exercise tolerance in patients with ankylosing spondylitis. Clin. Exp. Rheumatol., 2000, 18(4), 503506.

[7] Sahin, G., Calikoğlu, M., Ozge, C., et al.: Respiratory muscle strength but not BASFI score relates to diminished chest expansion in ankylosing spondylitis. Clin. Rheumatol., 2004, 23(3), 199-202.

[8] Meadway, J.: Ulcerative colitis, colitic spondylitis and associated apical pulmonary fibrosis. Proc. R. Soc. Med., 1974, 67(5), 324325 .

[9] Dincer, U., Cakar, E., Kiralp, M. Z., et al.: The pulmonary involvement in rheumatic diseases: pulmonary effects of ankylosing spondylitis and its impact on functionality and quality of life. Tohoku J. Exp. Med., 2007, 212(4), 423-430.

[10] Ince, G., Sarpel, T., Durgun, B., et al.: Effects of a multimodal exercise program for people with ankylosing spondylitis. Phys. Ther., 2006, 86(7), 924-935.

[11] Karatepe, A. G., Akkoc, Ү., Akar, S., et al.: The Turkish versions of the Bath Ankylosing Spondylitis and Dougados Functional Indices: reliability and validity. Rheumatol. Int., 2005, 25(8), 612-618.

[12] Van der Linden, S., Valkenburg, H. A., Cats, A.: Evaluation of diagnostic criteria for ankylosing spondylitis: a proposal for modification of the New York criteria. Arthritis Rheum., 1984, 27(4), 361-368.

[13] Katona, F., Siegler, J.: Medical rehabilitation. [Orvosi rehabilitáció.] Medicina Könyvkiadó, Budapest, 1999. [Hungarian]

[14] Pellegrino, R., Viegi, G., Brusasco, V., et al.: Interpretative strategies for lung function tests. Eur. Respir. J., 2005, 26(5), 948968.

[15] Cotes, J. E., Chinn, D. J., Quanjer, P. H., et al.: Standardization of the measurement of transfer factor (diffusing capacity). Report Working Party Standardization of Lung Function Tests, European Community for Steel and Coal. Official Statement of the
European Respiratory Society. Eur. Respir. J. 6(Suppl. 16), 1993, 41-52.

[16] Sue, D. Y., Wasserman, K., Moricca, R. B., et al.: Metabolic acidosis during exercise in patients with chronic obstructive pulmonary disease. Use of the $\mathrm{V}$-slope method for anaerobic threshold determination. Chest, 1988, 94(5), 931-938.

[17] Campbell, S. C.: A comparison of the maximum voluntary ventilation with the forced expiratory volume in one second: an assessment of subject cooperation. J. Occup. Med., 1982, 24(7), 531-533.

[18] Borg, G. A.: Psychophysical bases of perceived exertion. Med. Sci. Sports Exerc., 1982, 14(5), 377-381.

[19] Bozsóky, S., Irányi, J.: Practical use of physiotherapy. The Practitioner's Library, Vol. 189. [A fizioterápia gyakorlati alkalmazása. A gyakorló orvos könyvtára 189.] Medicina Könyvkiadó, Budapest, 1978. [Hungarian]

[20] Varga, J., Porszasz, J., Boda, K., et al.: Supervised high intensity continuous and interval training vs. self-paced training in COPD. Respir. Med., 2007, 101(11), 2297-2304.

[21] Fischer, L. R., Cawley, M. I., Holgate, S. T.: Relation between chest expansion, pulmonary functions, and exercise tolerance in patients with ankylosing spondylitis. Ann. Rheum. Dis., 1990, $49(11), 921-925$.

[22] Calin, A., Garrett, S., Whitelock, H., et al.: A new approach to defining functional ability in ankylosing spondylitis: the development of the Bath Ankylosing Spondylitis Functional Index (BASFI). J. Rheumatol., 1994, 21(12), 2281-2285.

[23] Calin, A., Nakache, J. P., Gueguen, A., et al.: Defining disease activity in ankylosing spondylitis: is a combination of variables (Bath Ankylosing Spondylitis Disease Activity Index) an appropriate instrument? Rheumatology (Oxford), 1999, 38(9), 878882.

[24] Izsák, J., Juhász-Nagy, P., Varga, Z.: Introduction to biomathematics. [Bevezetés a biomatematikába.] Tankönyvkiadó, Budapest, 1982. [Hungarian]

[25] Lehmann, E. L.: Testing statistical hypotheses. Wadsworth \& Brooks/Cole Advanced Books, Pacific Grove, CA, 1991.

[26] Vanderschueren, D., Decramer, M., Van den Daele, P., et al.: Pulmonary function and maximal transrespiratory pressures in ankylosing spondylitis. Ann. Rheum. Dis., 1989, 48(8), 632-635.

[27] Tanoue, L. T.: Pulmonary involvement in collagen vascular disease: a review of the pulmonary manifestations of the Marfan syndrome, ankylosing spondylitis, Sjögren's syndrome and relapsing polychondritis. J. Thorac. Imaging, 1992, 7(2), 62-77.

[28] Franssen, M. J., van Herwaarden, C. L., van de Putte, L. B., et al.: Lung function in patients with ankylosing spondylitis. A study of the influence of disease activity and treatment with nonsteroidal anti-inflammatory drugs. J. Rheumatol., 1986, 13(5), 936-940.

[29] Feltelius, N., Hedenstrom, H., Hillerdal, G., et al.: Pulmonary involvement in ankylosing spondylitis. Ann. Rheum. Dis., 1986, $42,736-740$

[30] Beals, C. A., Lampman, R. M., Banwell, B. F., et al.: Measurement of exercise tolerance in patients with rheumatoid arthritis and osteoarthritis. J. Rheumatol., 1985, 12(3), 458-461.

[31] Carter, R., Riantawan, P., Banham, S. W., et al.: An investigation of factors limiting aerobic capacity in patients with ankylosing spondylitis. Respir. Med., 1999, 93(10), 700-708.

[32] Elliott, C. G., Hill, T. R., Adams, T. E., et al.: Exercise performance of subjects with ankylosing spondylitis and limited chest expansion. Bull. Eur. Physiopathol. Respir., 1985, 21(4), 363368.

[33] Mau, W., Zeidler, H., Mau, R., et al.: Outcome of possible ankylosing spondylitis in a 10 years follow-up study. Clin. Rheumatol., 1987, 6(Suppl. 2), 60-66

[34] Ringsdal, V. S., Helin, P.: Ankylosing spondylitis - education, employment and invalidity. Dan. Med. Bull., 1991, 38(3), 282284. 
[35] Simon, L., Blotman, F.: Exercise therapy and hydrotherapy in the treatment of the rheumatic diseases. Clin. Rheum. Dis., 1981, $7(2), 337-347$

[36] Chakera, T. M., Howarth, F. H., Kendall, M. J., et al.: The chest radiograph in ankylosing spondylitis. Clin. Radiol., 1975, 26(4), 455-459.

[37] Fenlon, H. M., Casserly, I., Sant, S. M., et al.: Plain radiographs and thoracic high resolution CT in patients with ankylosing spondylitis. Am. J. Roentgenol., 1997, 168(4), 1067-1072.

[38] Rosenow, E., Strimlan, C. V., Muhm, J. R., et al.: Pleuropulmonary manifestations of ankylosing spondylitis. Mayo Clin. Proc., 1977, 52(10), 641-649.

[39] Dougados, M.: Diagnostic features of ankylosing spondylitis. Br. J. Rheumatol., 1995, 34(4), 301-303.

[40] Ince, G., Sarpel, T., Durgun, B., et al.: Effects of a multimodal exercise program for people with ankylosing spondylitis. Phys. Ther., 2006, 86(7), 924-935.

[41] Fernández-de-Las-Peñas, C., Alonso-Blanco, C., Alguacil-Diego, I. M., et al.: One-year follow-up of two exercise interventions for the management of patients with ankylosing spondylitis: a ran domized controlled trial. Am. J. Phys. Med. Rehabil., 2006, 85(7), 559-567.

[42] Van Tubergen, A., Hidding, A.: Spa and exercise treatment in ankylosing spondylitis: fact or fancy? Best Pract. Res. Clin. Rheumatol., 2002, 16(4), 653-666.

[43] Dagfinrud, H., Kvien, T. K., Hagen, K. B.: Physiotherapy interventions for ankylosing spondylitis. Cochrane Database Syst. Rev., 2004, (4), CD 002822.

[44] Fernández-de-Las-Peñas, C., Alonso-Blanco, C., Morales-Cabezas, $M$., et al.: Two exercise interventions for the management of patients with ankylosing spondylitis: a randomized controlled trial. Am. J. Phys. Med. Rehabil., 2005, 84(6), 407-419.

(Hegedûs Béla dr., 2025 Visegrád, Gizella telep e-mail: arthrodent@freemail.hu)

\section{Pályázat}

Az egészségértés - a health literacy - azt a képességünket jelenti, hogy mennyire tudunk egészségügyi kérdésekben eligazodni, mennyire értjük az egészségügyi információkat. Az Innovatív Gyógyszergyártók Egyesülete (AIPM) 2015 nyarán végzett országos, reprezentatív kutatása alapján Magyarországon minden második embernek komoly problémái vannak e területen.

Az Innovatív Gyógyszergyártók Egyesülete (AIPM) kiemelkedő fontosságúnak tartja az egészségtudatosságot és a jobb egészségértést, ezért pályázatot hirdet „Nekem Szól! Egészségértés Díj 2016.” címmel.

A pályázat célja, hogy feltérképezze, és a közvéleménnyel megossza a legjobb egészségértést, egészségtudatosságot fejlesztő hazai programokat és gyakorlatokat, amelyek elősegítik a betegek, illetve a laikusok egészségügyi kérdésekben történő tájékozódását, a kapott egészségügyi információk megértését és felhasználását.

Az Egészségértés Díjra pályázhat minden Magyarországon tartózkodó magánszemély, természetes és jogi személy, civil entitás és állami szerv. A pályázat során 4 kategóriába (egészségügyi intézmények, egészségügyi szakemberek, betegszervezetek, közvetlen lakossági kommunikáció) lehet majd beküldeni a nevezéseket.

A pályázatokat szakmai zsüri bírálja el, a kategórianyertesek díjazása bruttó $200000 \mathrm{Ft}$, a legkiemelkedőbb pályázat pedig elnyeri a „Nekem Szól! Egészségértés Díj 2016.” bruttó 400000 forintos födíját.

A pályázatra 2016. január 1. és október 14. között Magyarországon futó egészségértést támogató projektek/ kezdeményezések nevezhetőek. A részletes pályázati kiírás megtalálható a www.aipm.hu honlapon. 